\title{
A systematic determination of diffusion coefficients of trace elements in open and restricted diffusive layers used by the diffusive gradients in a thin film technique
}

Amir Houshang Shiva, Peter R. Teasdale*, William W. Bennett, David T. Welsh Environmental Futures Research Institute, Griffith University, Gold Coast campus, QLD 4222, Australia

*Corresponding Author: p.teasdale@griffith.edu.au

Ph: +61 755528358

Fax: +61 755528067 


\section{Abstract}

A systematic comparison of the diffusion coefficients of cations ( $\mathrm{Al}, \mathrm{Cd}, \mathrm{Co}, \mathrm{Cu}, \mathrm{Mn}, \mathrm{Ni}, \mathrm{Pb}$, $\mathrm{Zn}$ ) and oxyanions (Al, As, Mo, Sb, V, W) in open (ODL) and restricted (RDL) diffusive layers used by the DGT technique was undertaken. Diffusion coefficients were measured using both the diffusion cell $\left(\mathrm{D}_{\text {cell }}\right)$ method at $\mathrm{pH} 4.00$ and the DGT time-series $\left(\mathrm{D}_{\mathrm{DGT}}\right)$ method at $\mathrm{pH} 4.01$ and $7.04(\mathrm{pH} 8.30$ was used instead of 7.04 for $\mathrm{Al}$ ) using the ChelexMetsorb mixed binding layer. The performance of Chelex-Metsorb as a new DGT binding layer for Al uptake was also evaluated for the first time. Reasonable agreement was observed between $\mathrm{D}_{\text {cell }}$ and $\mathrm{D}_{\mathrm{DGT}}$ measurements for both ODL and RDL, except for $\mathrm{V}$ and $\mathrm{W}$. The ratios of $\mathrm{D}_{\text {cell }} / \mathrm{D}_{\mathrm{DGT}}$ for $\mathrm{V}$ of 0.44 and 0.39 , and for $\mathrm{W}$ of 0.66 and 0.63 with ODL and RDL respectively, were much lower due to the formation of a high proportion of polyoxometalate species at the higher concentrations required with the $D_{\text {cell }}$ measurements. This is the first time that $\mathrm{D}$ values have been reported for several oxyanions using RDL. Except for $\mathrm{Al}$ at $\mathrm{pH}$ 8.30 with ODL, all $\mathrm{D}_{\mathrm{DGT}}$ measurements were retarded relative to diffusion coefficients in water $\left(\mathrm{D}_{\mathrm{W}}\right)$ for both diffusive hydrogels. Diffusion in RDL was further retarded compared with ODL, for all elements (0.66-0.78) with both methods. However, the degree of retardation observed changed for cations and anions at each $\mathrm{pH}$. At $\mathrm{pH} 7.04$ cations had a slightly higher $\mathrm{D}_{\mathrm{DGT}}$ and oxyanions had a slightly lower $\mathrm{D}_{\mathrm{DGT}}$ than at $\mathrm{pH} 4.01$ for both ODL and RDL. It is proposed that this is due to partial formation of acrylic acid functional groups ( $\mathrm{p} K_{\mathrm{a}} \approx 4.5$ ), which would be fully deprotonated at $\mathrm{pH} 7.04$ (negative) and mostly protonated at $\mathrm{pH} 4.01$ (neutral). As $\mathrm{Al}$ changes from being cationic at $\mathrm{pH} 4.01$ to anionic at $\mathrm{pH} 8.30$ the results were more complex.

Keywords: metal diffusion coefficients; passive sampler measurements; diffusion cell measurements; open diffusive gel; restricted diffusive gel; retarded diffusion 


\section{Introduction}

In the last two decades the diffusive gradients in a thin film (DGT) technique has demonstrated its capability as an effective kinetic passive sampler for selective measurement of many elements in water [1-5]. An adsorbent material embedded in a polyacrylamide hydrogel (binding layer) accumulates reactive analyte species after they diffuse through another layer of known thickness. This diffusive layer $(\Delta \mathrm{g}, \mathrm{cm})$ usually consists of a protective membrane and a polyacrylamide hydrogel [2]. The concentration $\left(\mathrm{C}, \mathrm{ng} \mathrm{mL}^{-1}\right)$ of analytes in the measured solution can be calculated using Equation 1 [2], where $\mathrm{D}\left(\mathrm{cm}^{2} \mathrm{~s}^{-1}\right)$ is the diffusion coefficient of the element species in the hydrogel; $t(s)$ is the deployment time; A $\left(\mathrm{cm}^{2}\right)$ is the area of the gel exposed to the solution; and, M (ng) is the mass of accumulated analytes on the binding gel, determined by eluting the analytes from the binding layer [6-9] corrected for the elution efficiency.

$\mathrm{C}=\mathrm{M} \Delta \mathrm{g} / \mathrm{DtA}$

For elements with complex speciation and multiple labile forms, such as many cationic metals, the DGT concentration provides an operational measure of the free metal ions required to produce the accumulated mass [10]. For elements with one or two reactive species only, such as some oxyanions, the estimated concentration can be interpreted directly [7]. The diffusive boundary layer (DBL), a layer of quiescent water at all surfaces through which mass transport occurs only by diffusion, also needs to be determined for accurate DGT measurements as it can vary considerably $(0.023-0.065 \mathrm{~cm})$ [11-13].

The selectivity of DGT measurements can be regulated by using different binding layer materials $[4,6,14]$ or by using a hydrogel with a different pore size as the diffusive layer [15]. For the latter approach, the diffusion coefficients of free metals change with differing pore sizes but this can also effectively exclude larger species such as complexes with natural 
organic matter and colloids $[15,16]$. Although various diffusive gels have been used previously, most applications have employed a type of polyacrylamide hydrogel with pore sizes $>5 \mathrm{~nm}$ (open diffusive layer, ODL) $[2,13,17]$, which uses a proprietary agarose-based cross-linker [4]. Some investigators, however, have used polyacrylamide gel with a bisacrylamide cross-linker, which results in smaller pore sizes $<1 \mathrm{~nm}$ (restricted diffusive layer, RDL) $[10,18,19]$. The RDL is thought to allow measurement of only free ions and small inorganic complexes, while the ODL also allows diffusion of many organic complexes [10, 20].

For determination of metal concentrations in solution by the DGT technique, with either ODL or RDL, it is essential to have an accurate estimation of analyte diffusion coefficients (D) in each diffusive layer. This then allows DGT measurements to be made without further calibration or validation. These D values for metals and oxyanions in the ODL have been determined using diffusion cell [15] or DGT time-series [17] methods. Few studies have measured the diffusion coefficient of analytes in the RDL [21, 22]; these have only used the diffusion cell method and the results seem to be highly variable. Consequently, this study has systematically determined and compared the diffusion coefficients, using both the diffusion cell and time-series DGT methods, for a wide range of cations ( $\mathrm{Al}, \mathrm{Cd}, \mathrm{Co}, \mathrm{Cu}, \mathrm{Mn}, \mathrm{Ni}, \mathrm{Pb}$, $\mathrm{Zn}$ ) and oxyanions (Al, As, Mo, Sb, V, W) with both ODL and RDL. The recent mixed binding layer (MBL, containing both Chelex and Metsorb) described by Panther et al. [23] was used for the DGT time-series measurement of diffusion coefficients at both acidic and neutral $\mathrm{pH}$ to determine the effect of speciation changes on the diffusion coefficients. The performance of this DGT-MBL was also evaluated for Al uptake, based on the findings of Panther et al. [9] that DGT-Chelex measures Al in weakly acid waters and that DGT-Metsorb measures $\mathrm{Al}$ in seawater and other slightly basic waters. These data will support many 
subsequent studies in which these metals are measured and fill a critical gap in the DGT research literature.

\section{Experimental}

\subsection{General procedures}

All plastic equipment was soaked in 10\% nitric acid (AR grade, Merck) for at least 24 hours prior to rinsing with deionised water (Milli-Q Element, Millipore, >18.2 $\mathrm{MOhms} \mathrm{cm}^{-1}$ ). All experiments were done in an ISO Class 6 (ISO 14644-1) clean room, wearing powder free latex gloves (Microtouch Dermaclean, Ansell) and hydrogel casting was conducted in a fume hood. Stock solutions $\left(1000 \mathrm{mg} \mathrm{L}^{-1}\right)$ were prepared freshly for each element by dissolving the relevant salt (all AR grade) in deionised water. To minimize the risk of metal precipitation at such high concentrations, none of the stock solutions were mixed. Aluminium nitrate $\left[\mathrm{Al}\left(\mathrm{NO}_{3}\right)_{3} \cdot 9 \mathrm{H}_{2} \mathrm{O}\right]$, manganese chloride $\left[\mathrm{MnCl}_{2} \cdot 4 \mathrm{H}_{2} \mathrm{O}\right]$, cobalt nitrate $\left[\mathrm{Co}\left(\mathrm{NO}_{3}\right)_{2} \cdot 6 \mathrm{H}_{2} \mathrm{O}\right]$, nickel chloride $\left[\mathrm{NiCl}_{2}\right]$, copper chloride $\left[\mathrm{CuCl}_{2} \cdot 2 \mathrm{H}_{2} \mathrm{O}\right]$, zinc chloride $\left[\mathrm{ZnCl}_{2}\right]$, cadmium nitrate $\left[\mathrm{Cd}\left(\mathrm{NO}_{3}\right)_{2} \cdot 4 \mathrm{H}_{2} \mathrm{O}\right]$, lead nitrate $\left[\mathrm{Pb}\left(\mathrm{NO}_{3}\right)_{2}\right]$, ammonium metavanadate $\left[\mathrm{NH}_{4} \mathrm{VO}_{3}\right]$, sodium arsenate $\left[\mathrm{Na}_{2} \mathrm{HAsO}_{4} \cdot 7 \mathrm{H}_{2} \mathrm{O}\right]$, sodium molybdate $\left[\mathrm{Na}_{2} \mathrm{MoO}_{4} \cdot 2 \mathrm{H}_{2} \mathrm{O}\right]$, potassium antimonate $\left[\mathrm{KSb}(\mathrm{OH})_{6}\right]$ and sodium tungstate $\left[\mathrm{Na}_{2} \mathrm{WO}_{4} \cdot 2 \mathrm{H}_{2} \mathrm{O}\right]$ were used to prepare the required stock solutions. 


\subsection{Preparation of hydrogels}

\subsubsection{Diffusive layers}

ODL and RDL hydrogels, with a final thickness of $0.08 \mathrm{~cm}$, were prepared according to Scally et al. [21] with minor modifications. For ODL hydrogels, a gel stock solution was made by mixing $23.75 \mathrm{ml}$ of Milli-Q water, $18.75 \mathrm{ml}$ of $40 \%$ acrylamide solution (Bio-Rad) and $7.5 \mathrm{ml}$ of proprietary agarose-based cross-linker (DGT Research Ltd., UK). For each 10 $\mathrm{ml}$ of gel stock solution, $70 \mu \mathrm{l}$ of fresh ammonium persulphate solution (10\%, Chem-Supply) and $25 \mu \mathrm{l}$ of N,N,N,N-tetramethylethylenediamine solution (TEMED, Bio-Rad) were added, while being stirred vigorously. The solution was immediately cast between two acid washed glass plates (separated by a $0.05 \mathrm{~cm}$ thick plastic spacer) and placed in the oven at $45^{\circ} \mathrm{C}$ for 45-60 minutes. Following polymerisation, the gels were rinsed in deionised water for 24 hours (water changed at least three times) to allow unreacted reagents to diffuse out of the gels. The hydrated diffusive gels $(\sim 0.08 \mathrm{~cm})$ were stored in $\mathrm{NaNO}_{3}$ solution $\left(0.01 \mathrm{~mol} \mathrm{~L}^{-1}\right.$, Chem-Supply) at room temperature.

For RDL hydrogels, a gel solution was prepared by mixing $40 \%$ acrylamide/bisacrylamide solution (Sigma-Aldrich) in a 1:1.66 ratio with chilled Milli-Q water. Then $70 \mu$ of $10 \%$ ammonium persulphate solution and $20 \mu \mathrm{l}$ of TEMED solution were added for every $10 \mathrm{ml}$ of gel solution whilst stirring vigorously. Gel solution was cast between two acid washed glass plates separated by a $0.075 \mathrm{~cm}$ thick spacer and allowed to polymerise at room temperature for 20-30 minutes. After rinsing in deionised water for $24 \mathrm{~h}$ (water changed at least three times), the gels were stored in $0.01 \mathrm{~mol} \mathrm{~L}^{-1} \mathrm{NaNO}_{3}$ solution at room temperature.

Three hydrated ODL and RDL were selected randomly, a filter membrane placed on one face (as in the DGT application), and the overall thickness of $\Delta \mathrm{g}$ was measured using digital vernier calipers [15]. 


\subsubsection{Mixed binding layer}

A new binding layer described by Panther and co-workers [23] was used in this study for simultaneous measurement of cations and oxyanions. The binding gel consists of a mixture of Chelex and Metsorb resins. Metsorb was cleaned with $\mathrm{HNO}_{3}$ and $\mathrm{NaOH}$ prior to mixing with Chelex [9]. $2 \mathrm{~g}$ of dry Chelex-100 (sodium form, 200-400 mesh, Bio-Rad) and $1 \mathrm{~g}$ of cleaned Metsorb (Graver Technologies, USA) were used per $10 \mathrm{ml}$ of acrylamide gel stock. $60 \mu \mathrm{l}$ of ammonium persulphate (10\%) and $20 \mu 1$ of TEMED solutions were added while being stirred vigorously. The solution was then immediately cast between acid-washed glass plates (separated by a $0.025 \mathrm{~cm}$ thick plastic spacer) and polymerised for $1 \mathrm{~h}$ at $45^{\circ} \mathrm{C}$. The gels were rinsed in deionised water for $24 \mathrm{~h}$ (three times water change) and hydrated binding gels (0.04 $\mathrm{cm}$ thick) were stored in deionised water at $<4^{\circ} \mathrm{C}$.

\subsection{Diffusion coefficient measurements}

\subsubsection{Time-series DGT deployments}

DGT samplers (purchased from DGT Research Ltd., Lancaster, UK) were assembled as described previously [2]. The DGT samplers were deployed in test solutions containing $20 \mu \mathrm{g}$ $\mathrm{L}^{-1}$ of each analyte. Large polyethylene containers (7 litres) were used as exposure chambers to minimize changes in concentration caused by DGT uptake. The experiments were carried out separately at $\mathrm{pH} 4.01$ and $\mathrm{pH} 7.04\left[0.01 \mathrm{~mol} \mathrm{~L}^{-1} \mathrm{NaNO}_{3} / 0.004 \mathrm{~mol} \mathrm{~L}^{-1} \mathrm{Mg}\left(\mathrm{NO}_{3}\right)_{2}\right]$ using mixed metal solutions. Magnesium nitrate was added to the mixed solution in order to minimize metal surface adsorption [24]. Aluminium was not included in the $\mathrm{pH} 7.04$ solution and a separate experiment was performed at $\mathrm{pH} 8.30\left[0.01 \mathrm{~mol} \mathrm{~L}^{-1} \mathrm{NaNO}_{3} / 0.0005 \mathrm{~mol} \mathrm{~L}^{-1}\right.$ $\mathrm{NaHCO}_{3}$ as buffer] to avoid formation of insoluble aluminium hydroxide at $\mathrm{pH}$ 6-7. To 
provide a well-mixed solution and ensure a constant fluid velocity during the experiment, the solutions were stirred continuously. Before deploying the DGT samplers, the solutions were left for $72 \mathrm{~h}$ to stabilize and the $\mathrm{pH}$ was adjusted to the desired values by adding diluted $\mathrm{HNO}_{3}$ or $\mathrm{NaOH}$. pH was measured using a Mettler-Toledo $\mathrm{pH}$ meter (FiveGo, FG2). Four sets of triplicate DGT-MBL with ODL or RDL were deployed in the solutions and retrieved every 8 hours up to $32 \mathrm{~h}$. The DGT samplers were then rinsed with deionised water and stored at $<4^{\circ} \mathrm{C}$ until analysis (Section 2.4).

A linear regression and equation is obtained between the diffused mass and time. The slope of this line was used to calculate the effective diffusion coefficient for each metal and oxyanion in the ODL and RDL (Equation 2) [6]:

$\mathrm{D}=\operatorname{slope}(\Delta \mathrm{g}) / \mathrm{CA}$

where $\mathrm{C}$ represents the average metal concentration over time in the test solution. The thickness of DBL was not factored in diffusion path, assuming the solutions were well stirred. Measured diffusion coefficients were corrected for temperature using the Stokes-Einstein equation [2]. Upon deployment and removal of each set of DGT samplers, $0.45 \mu \mathrm{m}$ filtered and unfiltered grab samples of the test solution were collected, acidified to $2 \%(\mathrm{v} / \mathrm{v}) \mathrm{HNO}_{3}$ (Baseline, High Purity Standards) and stored at $<4^{\circ} \mathrm{C}$ to check for possible analyte precipitation. $\mathrm{pH}$ and temperature of the test solutions were measured with each grab sample being collected $\left(24 \pm 1^{\circ} \mathrm{C}\right.$ for $\mathrm{pH} 4.01$ and $26 \pm 1^{\circ} \mathrm{C}$ for $\mathrm{pH} 7.04$ and 8.30$)$.

\subsubsection{Diffusion cell}

The procedure for the measurement of diffusion coefficients of free metal ions through polyacrylamide hydrogels using a diffusion cell apparatus has been described previously [8, 15]. Two $70 \mathrm{ml}$ Perspex diffusion cell compartments with a $1.60 \mathrm{~cm}$ diameter window were 
clamped together with a diffusive gel $(0.08 \mathrm{~cm}$ thickness $)$ and a filter membrane $(0.01 \mathrm{~cm}$ thickness) in the window. The compartment to which the membrane faced became the source compartment. To prevent excessive compression of the gel, a plastic spacer of thickness 0.05 $\mathrm{cm}$ was also placed between the compartments but not overlapping with the gel. Both compartments were filled with $70 \mathrm{ml}$ of $0.01 \mathrm{~mol} \mathrm{~L}^{-1} \mathrm{NaNO}_{3}$ solution ( $\mathrm{pH} 4.00$ ). The source compartment had a final concentration of $5 \mathrm{mg} \mathrm{L}^{-1}$ of either cations ( $\mathrm{Al}, \mathrm{Cd}, \mathrm{Co}, \mathrm{Cu}, \mathrm{Mn}, \mathrm{Ni}$, $\mathrm{Pb}, \mathrm{Zn}$ ) or oxyanions (As, Mo, $\mathrm{Sb}, \mathrm{V}, \mathrm{W})$. To minimize the risk of precipitation at these necessarily high concentrations, cation and oxyanion solutions were measured separately for each diffusive gel type. Therefore, four separate diffusion cell measurements were done to determine diffusion coefficients for each element in the ODL and RDL. The solutions in both compartments were stirred continuously by a magnetic stirrer. After allowing $20 \mathrm{~min}$ for diffusion to reach a steady state, $0.5 \mathrm{ml}$ samples were taken from both sides at intervals of 10 minutes over a period of $2 \mathrm{~h}$. These samples were preserved by adding $\mathrm{HNO}_{3}$ to a final concentration of $2 \%$ and stored at $<4^{\circ} \mathrm{C}$. Following analysis, the diffusion coefficient of each analyte in the ODL and RDL was calculated from the slope of the accumulated mass versus time using Equation 2, assuming the thickness of DBL on each side of the gel is negligible. During the experiments, $\mathrm{pH}$ was checked regularly and temperature was maintained at $22 \pm 1^{\circ} \mathrm{C}$ for cations and $21 \pm 1^{\circ} \mathrm{C}$ for oxyanions.

\subsection{Sample analysis and method detection limits}

After removal from the DGT samplers, the elements in the MBL were eluted in $1 \mathrm{ml}$ of $1 \mathrm{~mol}$ $\mathrm{L}^{-1} \mathrm{HNO}_{3}$ and then, after rinsing in deionised water, $1 \mathrm{ml}$ of $1 \mathrm{~mol} \mathrm{~L}^{-1} \mathrm{NaOH}$, each for $24 \mathrm{~h}$ [23]. To elute $\mathrm{Sb}$, the gels were then immersed in $1 \mathrm{ml}$ of $1 \mathrm{~mol} \mathrm{~L}^{-1} \mathrm{NaOH} / 1 \mathrm{~mol} \mathrm{~L}^{-1} \mathrm{H}_{2} \mathrm{O}_{2}$ for another $24 \mathrm{~h} \mathrm{[8].} \mathrm{All} \mathrm{the} \mathrm{eluents} \mathrm{were} \mathrm{combined,} \mathrm{diluted} \mathrm{10-fold} \mathrm{and} \mathrm{acidified} \mathrm{to} 2 \%$ 
$\mathrm{HNO}_{3}$ prior to analysis by ICP-MS. Solution grab samples were analysed directly without a dilution step.

The accumulated mass of analytes (M) on the Chelex-Metsorb mixed binding gel was calculated from analyte concentration in the eluent $\left(\mathrm{C}_{\mathrm{e}}\right)$ using Equation 3 [2].

$\mathrm{M}=\mathrm{C}_{\mathrm{e}}\left(\mathrm{V}_{\mathrm{e}}+\mathrm{V}_{\mathrm{g}}\right) / \mathrm{f}_{\mathrm{e}}$

Where $\mathrm{V}_{\mathrm{e}}$ is the volume of the eluent, $\mathrm{V}_{\mathrm{g}}$ is the volume of the gel $(0.2 \mathrm{ml})$ and $\mathrm{f}_{\mathrm{e}}$ is the elution factor for each element. The elution factors used in this study (except for Al) were those reported for the MBL by Panther et al. [23]. In terms of Al, an elution factor of 0.845 (using an average of Chelex and Metsorb gels) was utilized [9].

Elemental analyses were performed using an inductively coupled plasma mass spectrometer (ICP-MS, Agilent 7500a). All analytical standards for ICP-MS analysis were prepared with a multi-element standard (High Purity Standards) in 2\% (v/v) $\mathrm{HNO}_{3}$, which was the same matrix as the DGT samples. Every 15-20 samples, a quality control blank was measured followed by a $10 \mu \mathrm{g} \mathrm{L}^{-1}$ quality control standard (High Purity Standards). No significant change in ICP-MS sensitivity or carry-over was observed. Sc, Y and In were added to each sample as internal standards (100 $\mathrm{g} \mathrm{L}^{-1}$, High Purity Standards) to account for instrument drift. The recoveries of internal standard were within $88-99 \%$ of the measurements in the calibration standards and the quality control standards.

To monitor any contamination during synthesis and handling, DGT blanks were prepared in the same way as deployed DGT samplers and subjected to all procedures except for the deployment. Blanks were conducted in triplicate for each type of diffusive gel (total $=6$ ) and mass measurements were calculated using Equation 3. The calculated blank masses were 
subtracted from the accumulated mass of each analyte on the deployed DGT samplers to obtain the corrected mass values (ng).

Method detection limits (MDL, ng) were determined for all analytes (Table 1) as three times the standard deviation of the blanks $[8,25,26]$. The detection limits were also converted to concentration $\left(\mathrm{ng} \mathrm{mL}^{-1}\right)$ using the diffusion thickness $(\Delta \mathrm{g}, 0.09 \mathrm{~cm}$ including diffusive gel and filter membrane), deployment time $\left(\mathrm{t}, 32 \mathrm{~h}\right.$ at $\left.25^{\circ} \mathrm{C}\right)$, gel area $\left(\mathrm{A}, 3.14 \mathrm{~cm}^{2}\right)$ and diffusion coefficients, obtained from the current study (Table 2$)$, with either open $\left(\mathrm{D}_{\mathrm{ODL}}\right)$ or restricted $\left(\mathrm{D}_{\mathrm{RDL}}\right)$ diffusive layers.

\subsection{Speciation modelling}

The speciation program Visual MINTEQ (ver 3) [27] was used to determine the major cation and oxyanion species present in all solutions (in diffusion cell and DGT time-series experiments) to assist with interpretation of the results.

\section{Results and discussion}

\subsection{Speciation of solutions for diffusion coefficient measurements}

The dominant species in each solution for the time-series DGT and diffusion cell measurements of diffusion coefficients are given respectively in Table S1 and Table S2 in the Supporting Information (SI). These data indicate that each element was effectively $100 \%$ in solution for each measurement of D. This was supported by the ratios of filtered vs. unfiltered samples (0.94-1.04) measured for the DGT deployment solutions (Table S1). The cations and oxyanions were measured separately for the diffusion cell method, as higher concentrations 
were required. $\mathrm{Al}$ was measured separately at $\mathrm{pH} 8.30$, instead of at $\mathrm{pH} 7.04$, for the DGT method to ensure $\mathrm{Al}$ was in a soluble form $\left(\mathrm{Al}(\mathrm{OH})_{4}{ }^{-}\right)$.

\subsection{DGT blanks and method detection limits}

Table 1 shows the average DGT gel blanks and method detection limits (MDL) calculated for each element using DGT-MBL with both ODL and RDL. To lower the blank values, Metsorb was cleaned with $1 \mathrm{~mol} \mathrm{~L}^{-1} \mathrm{HNO}_{3}$ and $1 \mathrm{~mol} \mathrm{~L}^{-1} \mathrm{NaOH}$ prior to mixing with Chelex [9] as high detection limits have been reported for $\mathrm{Mn}, \mathrm{Ni}, \mathrm{Cu}, \mathrm{Zn}$ and $\mathrm{V}$ when using unwashed Metsorb [23]. All method detection limits in our study (except for $\mathrm{Al}$ and $\mathrm{Zn}$ ) were below 0.7

$\mathrm{ng} \mathrm{mL} \mathrm{m}^{-1}$ and in most cases $<0.2 \mathrm{ng} \mathrm{mL}^{-1}$, indicating low-level contamination of MBL. These estimated detection limits are in line with the previously reported MDL values for DGT-MBL [23], DGT-Metsorb [8, 26] and DGT-ferrihydrite [28]. The higher DGT blanks for Al and Zn are due to their presence in Metsorb, even with the acid-washing step, and are responsible for the higher MDL for these elements. Nonetheless, these MDL are still low for these elements compared to their likely concentrations in many waters. The MDLs were quite similar for ODL and RDL. The MDL for Al was higher for ODL and Zn for RDL; this is likely to be due to random variation in the blanks.

\subsection{Diffusion coefficient measurements using time-series DGT deployments}

The effective diffusion coefficients determined by the time-series DGT deployments $\left(\mathrm{D}_{\mathrm{DGT}}\right)$ of all elements measured in either ODL or RDL at different $\mathrm{pH}$ are shown in Table 2. The previously published diffusion coefficients with ODL using this method are given for comparison. This is the first time that $\mathrm{D}_{\mathrm{DGT}}$ values have been reported for RDL. The effect of 
the filter membrane is included in the effective diffusion coefficients as the $0.45 \mu \mathrm{m}$ pore size of the membrane is likely to have minimal effect on the diffusion coefficient of the measured species.

The results of accumulated mass versus time for each element in either ODL or RDL at each $\mathrm{pH}$ are shown in Figure 1 and Figure $\mathrm{S} 1$ for $\mathrm{pH} 7.04 / 8.30$ and $\mathrm{pH} 4.01$, respectively. The capability of the Chelex-Metsorb mixed binding layer for appropriate uptake of a wide range of cations and oxyanions has been confirmed previously [23]. However, aluminium uptake by DGT-MBL has not been investigated previously and this is the first validation of this measurement. Good linearity $\left(\mathrm{R}^{2}=0.9991\right.$ for $\mathrm{ODL}$ and $\mathrm{R}^{2}=0.9973$ for $\mathrm{RDL}$ at $\mathrm{pH} 8.30 ; \mathrm{R}^{2}$ $=0.9938$ for ODL and $\mathrm{R}^{2}=0.9974$ for $\mathrm{RDL}$ at $\mathrm{pH} 4.01$ ) was observed for $\mathrm{Al}$ over the $32 \mathrm{~h}$ experiment, indicating the suitability of this binding layer for DGT measurements of Al. Excellent linearity $\left(\mathrm{R}^{2} \geq 0.9901\right.$ for $\mathrm{ODL}$ and $\mathrm{R}^{2} \geq 0.9918$ for $\mathrm{RDL}$ at $\mathrm{pH} 7.04 ; \mathrm{R}^{2} \geq 0.9931$ for ODL and $\mathrm{R}^{2} \geq 0.9926$ for $\mathrm{RDL}$ at $\mathrm{pH} 4.01$ ) up to $32 \mathrm{~h}$ deployment was also observed for other analytes. This means that Equation 2 can be applied to determine $\underline{D}_{\mathrm{DGT}}$ for each element. The slopes of the regression lines from Figure 1 and Figure S1 (equations not shown) were used to calculate the diffusion coefficients (Table 2). These calculations were based on average concentrations in the solution, which at $\mathrm{pH} 7.04$ and $\mathrm{pH} 4.01$ ranged between 13.75-21.79 $\left(\mathrm{ng} \mathrm{mL}^{-1}\right)$ and 20.30-24.94 $\left(\mathrm{ng} \mathrm{mL}^{-1}\right)$, respectively. Aluminium had an average solution concentration of $21.57\left(\mathrm{ng} \mathrm{mL}^{-1}\right)$ at $\mathrm{pH} 8.30$. For all analytes, the average concentration at the end of the experiment was within $10 \%$ of the initial concentration.

ODL diffusion coefficient results for cations are generally within $2 \%-17 \%$ of literature D values (Table 2). The $\mathrm{D}_{\mathrm{DGT}}$ values for $\mathrm{Al}$ at $\mathrm{pH} 8.30$ and $\mathrm{pH} 4.01$ are within $8 \%$ and $2 \%$, respectively, of the values reported by Panther et al. [9] at $\mathrm{pH} 8.35$ and $\mathrm{pH} 5.05$ using Metsorb-DGT. Garmo and co-workers [17] calculated the Al diffusion coefficient at $\mathrm{pH} 5.25$ to be $5.10 \times 10^{-6} \mathrm{~cm}^{2} \mathrm{~s}^{-1}$ using DGT-Chelex, which is comparable with our results at $\mathrm{pH} 4.01$. 
For $\mathrm{Zn}$ and $\mathrm{Pb}$, although our values are very close to those of Panther et al. [23], they are $31 \%$ higher and $23 \%$ lower, respectively, than the values obtained by Garmo and co-workers [17]. It is promising that our diffusion coefficients $\left(\mathrm{D}_{\mathrm{DGT}}\right)$ for oxyanions in the ODL are in good agreement with previously reported values. A study carried out by Osterlund and coworkers [28] has reported relatively similar diffusion coefficients (within 15\%) for As (V), Mo (VI), Sb (V) and W (VI) at $\mathrm{pH}$ 4-8. However, some investigators have published diffusion coefficients $20-30 \%$ lower for $\mathrm{V}[26,28,29]$. The possible sources of this range of results include measurement uncertainties, differences in solution $\mathrm{pH}$ and concentrations resulting in differences in element speciation, diffusive boundary layer (DBL) effects, the thicknesses of the diffusive gel and differences in gel casting methods between laboratories.

The ratios of the diffusion coefficient of each element in RDL compared to that in ODL were similar for cations and oxyanions at each $\mathrm{pH}(<6 \%$ difference). The ratios of the RDL to ODL lie between 0.69 and 0.78 for cations and $0.66-0.77$ for oxyanions, which are similar to the previously reported data by Scally et al. [21] (ratios between 0.62 and 0.72). These results confirm that diffusion of free ions through RDL is retarded relative to ODL. Since both positive and negatively charged species are experiencing a similar slowing of their diffusion, the retardation of RDL relative to ODL is likely to be related to the smaller pore size of the RDL $(\approx 1 \mathrm{~nm})$, as suggested by Scally et al. [21]. However, since the radius of analyte ions are smaller $(<0.300 \mathrm{~nm})$ than the RDL pore size, the mechanism of retardation is likely due to the greater diffusional path length (tortuosity) within RDL compared with ODL $(\approx 5 \mathrm{~nm}$ pore size).

The calculated diffusion coefficients $\left(\mathrm{D}_{\mathrm{DGT}}\right)$ in either ODL or RDL are compared with the diffusion coefficient of free metal ions in water $\left(\mathrm{D}_{\mathrm{W}}\right)$ where such data exist [30]. These ratios lie between 0.73 and 0.90 in ODL and $0.57-0.70$ in RDL for cations, which are in good agreement with previous observations [21]. Oxyanions had ratios of $D_{\text {DGT }}$ to $D_{W}$ between 
0.62 and 0.82 in ODL (not including $\mathrm{Al}$ ) and 0.43-0.60 in RDL, which are consistent with results of Price et al. [26] and Luo et al. [29] for ODL and Uher et al. [22] for RDL. The average ratio $\left(\mathrm{D}_{\mathrm{DGT}} / \mathrm{D}_{\mathrm{W}}\right)$ using diffusion coefficients in ODL for cationic metals was $0.82 \pm 0.05(\mathrm{n}=15)$ and for oxyanions was $0.70 \pm 0.06(\mathrm{n}=8)$, not including the results for $\mathrm{Al}$ at $\mathrm{pH} 8.30$ (which were much higher perhaps due to the small radius of $\mathrm{Al}$ ions) and $\mathrm{V}$ (for which we could not find a published $\left.\mathrm{D}_{\mathrm{W}}\right)$. The average ratios $\left(\mathrm{D}_{\mathrm{DGT}} / \mathrm{D}_{\mathrm{W}}\right)$ using diffusion coefficients in RDL was $0.62 \pm 0.05(n=15)$ for cations and $0.49 \pm 0.06(n=8)$ for oxyanions. These findings suggest that diffusion of oxyanion species overall is retarded more than for cations.

This retardation of oxyanions relative to cations is interesting and consistent with the presence of a negative charge on the polyacrylamide hydrogels. Such an effect was used deliberately by Panther et al. [31] who impeded diffusion of arsenate anions with a negatively charged Nafion membrane, relative to neutral As(III) species. Acrylamide functional groups are known to undergo partial hydrolysis to acrylic acid groups which are negatively charged when deprotonated [32]. This reaction occurs quickly at basic $\mathrm{pH}$ but could still happen to some extent in neutral solutions with storage and may mean that storage time of the polyacrylamide hydrogels becomes an important factor. In this study all diffusive gels were used within 1 month of being prepared. On the other hand cationic free ions would undergo enhanced diffusion in the presence of negative charges. We should note that this is not due to the Donnan effect, which has been investigated for DGT previously [33, 34], as the ionic strength of the solution used for these measurements is too high [3]. A detailed discussion of the state of knowledge concerning the effect of charges in diffusive gels, including how to minimize them, and on DGT measurements has been provided by Davison and Zhang [3].

Further evidence in support of this proposed effect was observed with the $D_{\text {DGT }}$ measurements for each element at the two $\mathrm{pH}$ values. All cations had a lower $\mathrm{D}_{\mathrm{DGT}}$ at $\mathrm{pH}$ 
$4.01\left(4.28-7.70 \times 10^{-6}\right.$ vs $5.43-8.13 \times 10^{-6}$ at $\left.\mathrm{pH} 7.04\right)$ and all oxyanions had a higher $\mathrm{D}$ at $\mathrm{pH}$ $4.01\left(5.96-8.92 \times 10^{-6}\right.$ vs $5.59-8.24 \times 10^{-6}$ at $\left.\mathrm{pH} 7.04\right)$; the ratios of $\mathrm{D}_{\mathrm{DGT}}$ at $\mathrm{pH} 4.01$ and $\mathrm{pH}$ 7.04 (8.30 for $\mathrm{Al})$ are given for each element in Table 3 including measurement uncertainties. The effect was very small but consistent, which makes it unlikely to be due to random errors in the measurement. Acrylic acid functional groups have a $\mathrm{p} K_{\mathrm{a}}$ of about 4.5 [32] and would therefore be fully deprotonated at $\mathrm{pH} 7.04$ and above, with the strongest negative charge. These functional groups would be largely protonated at $\mathrm{pH} 4.01$ and thereby have a very slight negative charge only. Therefore, oxyanion species would be retarded more at neutral $\mathrm{pH}$ than at $\mathrm{pH} 4.01$, which is consistent with the results (Table 2). Conversely, cations are observed to have higher effective diffusion coefficients at neutral $\mathrm{pH}$ (Table 2) consistent with an enhanced diffusion effect due to the partial negative charge. The ODL and RDL are both affected to a similar extent within the measurement uncertainty (Table 3), which makes sense as they are both polyacrylamide hydrogels that differ only in the cross-linker used.

$\mathrm{Al}$ experiences a major change in speciation, with $\mathrm{Al}^{3+}$ predominant at $\mathrm{pH} 4.01(94 \%)$ and $\mathrm{Al}(\mathrm{OH})_{4}{ }^{-}$predominant at $\mathrm{pH} 8.30(99 \%)$, the biggest change in speciation for all the elements studied (Table S1). Assuming the negatively charged $\mathrm{Al}(\mathrm{OH})_{4}{ }^{-}$species are less hydrated than $\mathrm{Al}^{3+}$ species, the size of the diffusing $\mathrm{Al}$ species at $\mathrm{pH} 8.30$ is expected to be smaller than $\mathrm{pH}$ 4.01 [9]. Consequently, the $\mathrm{D}$ values measured for $\mathrm{Al}$ change substantially between $\mathrm{pH} 4.01$ and 8.30 (a ratio of 0.73 with ODL and 0.77 with RDL), while the effect is less than $13 \%$ for all elements. A consequence of this observation is that $\mathrm{D}$ values may vary somewhat from $\mathrm{pH}$ 4.5 to 5.5 from those reported here, but should vary little from 5.5 to neutral $\mathrm{pH}$, assuming there is no major change in element speciation. Nevertheless, using the different D values reported here will increase the accuracy of DGT measurements. It should be noted that this effect may become more pronounced if the hydrogels are stored for longer times. 


\subsection{Diffusion coefficient measurements using diffusion cell}

The diffusion coefficients obtained from the diffusion cell experiment $\left(\mathrm{D}_{\text {cell }}\right)$ are presented in Table 4 . These are the first $D_{\text {cell }}$ measurements made for several oxyanions. Separate plots of mass over time were obtained for each analyte in ODL $\left(\mathrm{R}^{2} \geq 0.9919\right)$ and $\mathrm{RDL}\left(\mathrm{R}^{2} \geq 0.9942\right)$ and the slopes were used to determine the diffusion coefficients using Equation 2 (see Figure S2 and Figure S3).

There is reasonable agreement $\left(<17 \%\right.$ difference) between our $D_{\text {cell }}$ values and earlier measurements with ODL for all elements (except for $\mathrm{V}$ and $\mathrm{W}$ ). The $\mathrm{D}_{\text {cell }}$ results for $\mathrm{V}$ and $\mathrm{W}$ were clearly different to literature values - up to $46 \%$ and $38 \%$ lower, respectively. These discrepancies, however, may be due to the different $\mathrm{pH}$ or analyte concentrations at which the experiments were carried out; for instance, our $\mathrm{D}_{\text {cell }}$ experiment was conducted at $\mathrm{pH} 4.00$ while other investigators have used $\mathrm{pH} 6$ or 7 for their experiments. These differences may affect the speciation of elements. Table S2 indicates that both V and $\mathrm{W}$ had major fractions of polyoxometalate species ( $\mathrm{V}$ was $23 \% \mathrm{H}_{3} \mathrm{~V}_{10} \mathrm{O}_{28}{ }^{3-}$ and $\mathrm{W}$ was $72 \% \mathrm{HW}_{7} \mathrm{O}_{24}{ }^{5-}$ ). Panther et al. [23] obtained a diffusion coefficient of $3.75 \times 10^{-6} \mathrm{~cm}^{2} \mathrm{~s}^{-1}$ for $\mathrm{V}$ at $\mathrm{pH} 4.01$ using the same diffusion cell, which is very similar to the value obtained in this study $\left(3.88 \times 10^{-6} \mathrm{~cm}^{2} \mathrm{~s}^{-1}\right)$. At lower $\mathrm{pH}$ the fraction of polyoxometalate species may increase.

The $\mathrm{D}_{\text {cell }}$ values obtained in RDL for metals are within $18 \%$ of the values reported from other studies $[21,22,35]$. The variations in our $\mathrm{D}_{\text {cell }}$ and literature values might arise from discrepancies in solution $\mathrm{pH}$ and composition, measurement of the diffusion area between two compartments of the diffusion cell and the dialysis cell construction, which may lead to differing DBL thickness. The ratio of the RDL values to the ODL values ranged from 0.68 to 0.75 (Table 4), which are generally consistent with ratios of D values obtained by the DGT time-series method (Table 2) and are similar to the previously reported data $[15,21]$. The 
average ratio of diffusion coefficients (RDL/ODL), regardless of method or $\mathrm{pH}$, for all cationic metals was $0.74 \pm 0.03(n=23)$ and for all oxyanionic elements was $0.71 \pm 0.03(n=16)$, with $\mathrm{Al}$ as a cation at $\mathrm{pH} 4.01$ and an anion at $\mathrm{pH}$ 8.30. These results confirm that the retardation effect of increased tortuosity in the RDL is very consistent and could perhaps be used to estimate a diffusion coefficient for the RDL from the known ODL diffusion coefficient.

Table 4 provides a comparison between the two methods used for diffusion coefficient measurements $\left(\mathrm{D}_{\text {cell }}\right.$ and $\left.\mathrm{D}_{\mathrm{DGT}}\right)$ at $\mathrm{pH} \approx 4$. It is immediately apparent that all the ratios of $\mathrm{D}_{\text {cell }} / \mathrm{D}_{\mathrm{DGT}}$ are less than $1(0.77-0.99$, excluding $\mathrm{V}$ and $\mathrm{W})$, which strongly suggests that values of $\mathrm{D}$ determined by diffusion cell method tend to be lower than those determined from DGT time-series results. This may be explained by the presence of a DBL on each side of the cell membrane, due to the cell design $[6,8]$. Even though both solutions have a fast stirring rate, the construction of such cells often results in a zone at each side of the membrane that may produce DBLs. Moreover, the effect of lateral diffusion within DGT samplers, which results in a higher accumulated mass of analyte, could also contribute to higher $\mathrm{D}_{\text {DGT }}$ values and has been reported by other investigators $[8,11]$. However, this effect is likely to be very small $(<5 \%)$.

For the ODL, $\mathrm{D}_{\text {cell }} / \mathrm{D}_{\mathrm{DGT}}$ ratios are within $5 \%$ for several of the cationic metals $(\mathrm{Al}, \mathrm{Cd}, \mathrm{Cu}$, and $\mathrm{Mn})$ and several more have ratios of approximately $0.9(\mathrm{Co}, \mathrm{Ni}, \mathrm{Pb}$ and $\mathrm{Zn})$. As is also at 0.9 , Mo and $\mathrm{Sb}$ are approximately 0.8 and $\mathrm{V}(0.44)$ and $\mathrm{W}(0.66)$ have very low ratios. It is likely the higher concentration solutions required for the diffusion cell measurements of D (5 $\mathrm{mg} \mathrm{L}^{-1}$ compared with $20 \mu \mathrm{g} \mathrm{L}^{-1}$ for the DGT measurement), resulting in higher proportion of polyoxometalate species for $\mathrm{V}$ and $\mathrm{W}$ (Table S2), are responsible for this observation [23]. A change in the speciation may also be responsible for the Mo result, although the speciation 
was determined to be the same for $\mathrm{Sb}$, which had similar ratios. The ratio of $\mathrm{D}$ values obtain between the two methods for RDL was quite similar (within 10\%) for all analytes.

\section{Conclusions}

This is the first study to systematically determine diffusion coefficients for a wide range of cationic and oxyanionic elements for the 'open' and 'restricted' hydrogels used as diffusive layers by the DGT technique, using both the DGT time-series (at $\mathrm{pH} 4.01$ and $7.04 ; 8.30$ for $\mathrm{Al}$ ) and the diffusion cell method (at $\mathrm{pH}$ 4.00). In several instances this is the first effective diffusion coefficient data reported for RDL ( $D_{\text {DGT }}$ for any elements and $D_{\text {cell }}$ for several oxyanions). The effect of using the RDL with its smaller pore size and therefore greater tortuosity was quite consistent. The average ratios of diffusion coefficients (RDL/ODL) are consistent enough to perhaps be used to estimate a diffusion coefficient for the RDL, in the absence of actual data, from the known ODL diffusion coefficient. This study also confirmed the suitability of Chelex-Metsorb as a new DGT binding layer for Al, especially for deployment in waters in which $\mathrm{Al}^{3+}$ is not predominant.

The two methods for determining diffusion coefficients at $\mathrm{pH} 4$ gave reasonable agreement using ODL for all cations and for As (ratios of $0.86-0.99$ for $\mathrm{D}_{\text {cell }} / \mathrm{D}_{\mathrm{DGT}}$ ). The $\mathrm{D}_{\text {cell }}$ results seem to be marginally lower than the $\mathrm{D}_{\text {DGT }}$ results, which is most likely due to the formation of a DBL on each side of the hydrogel membrane. The ratios for these elements with RDL were similar but tended to be somewhat lower in comparison, most likely due to the much higher concentrations used with the $\mathrm{D}_{\text {cell }}$ method resulting in a slight change of speciation. The ratios for Mo and $\mathrm{Sb}$ were about 0.8 , likely for the same reason. The ratios for $\mathrm{V}(0.39$ 0.44) and W (0.63-0.66) were much lower with both ODL and RDL due to the formation of a high proportion of polyoxometalate species with the $\mathrm{D}_{\text {cell }}$ measurements at higher solution 
concentrations. Overall, we recommend use of the DGT measurements for major experiments to determine diffusion coefficients at concentrations typical of natural waters and use of the diffusion cell for relatively quick quality control measurements, for instance, to compare batches of diffusive hydrogels.

The determination of $\mathrm{D}_{\text {DGT }}$ values at two different $\mathrm{pH}$ gave a useful insight into trends of diffusion coefficients for cationic and oxyanionic elements. Effective diffusion coefficients in ODL and RDL are retarded relative to diffusion coefficients in water at all $\mathrm{pH}$. Moreover, in both diffusive hydrogels the $D_{\text {DGT }}$ values for oxyanions were retarded more relative to $D_{W}$ than for cations. We propose that this is due to the formation of acrylic acid functional groups by hydrolysis of a small proportion of amide groups, which would give both diffusive hydrogels sites of negative charge, and enhancing diffusion of cations relative to oxyanions. Furthermore, a close inspection of variation in $\mathrm{D}_{\text {DGT }}$ values between $\mathrm{pH} 4.01$ and 7.04/8.30 revealed that $\mathrm{pH}$ was further modifying this trend slightly; at $\mathrm{pH} 7.04$ cations had a slightly higher $\mathrm{D}_{\mathrm{DGT}}$ and anions had a slightly lower $\mathrm{D}_{\mathrm{DGT}}$ than at $\mathrm{pH} 4.01$ with both ODL and RDL. This could be explained by the change in dissociation of any acrylic acid groups, because at $\mathrm{pH} 7.04 / 8.30$ the acrylic acid functional groups $\left(\mathrm{p} K_{\mathrm{a}} \approx 4.5\right)$ will be fully deprotonated and at $\mathrm{pH} 4.01$ they will only be very slightly deprotonated. This hypothesis is consistent with all observations in this study, there were no exceptions to these trends in the data and the effect was observed for both ODL and RDL. This factor may be responsible for some of the variation in literature diffusion coefficients, especially for oxyanions, and may have important implications for the preparation and storage of polyacrylamide diffusive layers. This finding strongly demonstrates the importance of comprehensive data on diffusion coefficients being available to improve the accuracy of DGT measurements in waters. 


\section{Supporting Information}

Additional information, as noted in the text, can be found in the online version of this article.

\section{Acknowledgements}

The authors would like to thank the School of Environment, Griffith University, for the provision of a $\mathrm{PhD}$ scholarship for A.H. Shiva. We also thank Graver Technologies (www.gravertech.com) for providing the Metsorb product used in this study.

\section{References}

[1] W. Davison, H. Zhang, In situ speciation measurements of trace components in natural waters using thin-film gels, Nature, 367 (1994) 546-548.

[2] H. Zhang, W. Davison, Performance Characteristics of Diffusion Gradients in Thin Films for the in Situ Measurement of Trace Metals in Aqueous Solution, Analytical Chemistry, 67 (1995) 3391-3400.

[3] W. Davison, H. Zhang, Progress in understanding the use of diffusive gradients in thin films (DGT) - back to basics, Environmental Chemistry, 9 (2012) 1-13.

[4] W. Davison, G. Fones, M. Harper, P. Teasdale, H. Zhang, Dialysis, DET and DGT: in situ diffusional techniques for studying water, sediments and soils, Buffle, J., Horvai, G. (Eds.). In situ monitoring of aquatic systems: chemical analysis and speciation, John Wiley \& Sons Ltd., Chichester, 2000, pp. 495569.

[5] J.G. Panther, P.R. Teasdale, W.W. Bennett, D.T. Welsh, H. Zhao, Comparing dissolved reactive phosphorus measured by DGT with ferrihydrite and titanium dioxide adsorbents: Anionic interferences, adsorbent capacity and deployment time, Analytica Chimica Acta, 698 (2011) 20-26.

[6] W.W. Bennett, P.R. Teasdale, J.G. Panther, D.T. Welsh, D.F. Jolley, New Diffusive Gradients in a Thin Film Technique for Measuring Inorganic Arsenic and Selenium(IV) Using a Titanium Dioxide Based Adsorbent, Analytical Chemistry, 82 (2010) 7401-7407.

[7] W.W. Bennett, P.R. Teasdale, J.G. Panther, D.T. Welsh, D.F. Jolley, Speciation of Dissolved Inorganic Arsenic by Diffusive Gradients in Thin Films: Selective Binding of Aslll by 3Mercaptopropyl-Functionalized Silica Gel, Analytical Chemistry, 83 (2011) 8293-8299.

[8] J.G. Panther, R.R. Stewart, P.R. Teasdale, W.W. Bennett, D.T. Welsh, H. Zhao, Titanium dioxidebased DGT for measuring dissolved $\mathrm{As}(\mathrm{V}), \mathrm{V}(\mathrm{V}), \mathrm{Sb}(\mathrm{V}), \mathrm{Mo}(\mathrm{VI})$ and $\mathrm{W}(\mathrm{VI})$ in water, Talanta, 105 (2013) 80-86.

[9] J.G. Panther, W.W. Bennett, P.R. Teasdale, D.T. Welsh, H. Zhao, DGT Measurement of Dissolved Aluminum Species in Waters: Comparing Chelex-100 and Titanium Dioxide-Based Adsorbents, Environmental Science \& Technology, 46 (2012) 2267-2275. 
[10] H. Zhang, W. Davison, Direct In Situ Measurements of Labile Inorganic and Organically Bound Metal Species in Synthetic Solutions and Natural Waters Using Diffusive Gradients in Thin Films, Analytical Chemistry, 72 (2000) 4447-4457.

[11] K.W. Warnken, H. Zhang, W. Davison, Accuracy of the Diffusive Gradients in Thin-Films Technique: Diffusive Boundary Layer and Effective Sampling Area Considerations, Analytical Chemistry, 78 (2006) 3780-3787.

[12] E. Uher, M.-H. Tusseau-Vuillemin, C. Gourlay-France, DGT measurement in low flow conditions: diffusive boundary layer and lability considerations, Environmental Science: Processes \& Impacts, 15 (2013) 1351-1358.

[13] H. Zhang, W. Davison, R. Gadi, T. Kobayashi, In situ measurement of dissolved phosphorus in natural waters using DGT, Analytica Chimica Acta, 370 (1998) 29-38.

[14] W.J.G.M. Peijnenburg, P.R. Teasdale, D. Reible, J. Mondon, W.W. Bennett, P.G.C. Campbell, Passive sampling methods for contaminated sediments: State of the science for metals, Integrated Environmental Assessment and Management, 10 (2014) 179-196.

[15] H. Zhang, W. Davison, Diffusional characteristics of hydrogels used in DGT and DET techniques, Analytica Chimica Acta, 398 (1999) 329-340.

[16] K.W. Warnken, W. Davison, H. Zhang, Interpretation of In Situ Speciation Measurements of Inorganic and Organically Complexed Trace Metals in Freshwater by DGT, Environmental Science \& Technology, 42 (2008) 6903-6909.

[17] Ø.A. Garmo, O. Røyset, E. Steinnes, T.P. Flaten, Performance Study of Diffusive Gradients in Thin Films for 55 Elements, Analytical Chemistry, 75 (2003) 3573-3580.

[18] M.R. Twiss, J.W. Moffett, Comparison of Copper Speciation in Coastal Marine Waters Measured Using Analytical Voltammetry and Diffusion Gradient in Thin-Film Techniques, Environmental Science \& Technology, 36 (2002) 1061-1068.

[19] W. Baeyens, A.R. Bowie, K. Buesseler, M. Elskens, Y. Gao, C. Lamborg, M. Leermakers, T. Remenyi, H. Zhang, Size-fractionated labile trace elements in the Northwest Pacific and Southern Oceans, Marine Chemistry, 126 (2011) 108-113.

[20] H. Zhang, In-Situ Speciation of $\mathrm{Ni}$ and $\mathrm{Zn}$ in Freshwaters: Comparison between DGT Measurements and Speciation Models, Environmental Science \& Technology, 38 (2004) 1421-1427.

[21] S. Scally, W. Davison, H. Zhang, Diffusion coefficients of metals and metal complexes in hydrogels used in diffusive gradients in thin films, Analytica Chimica Acta, 558 (2006) 222-229.

[22] E. Uher, H. Zhang, S. Santos, M.-H. Tusseau-Vuillemin, C. Gourlay-Francé, Impact of Biofouling on Diffusive Gradient in Thin Film Measurements in Water, Analytical Chemistry, 84 (2012) 31113118.

[23] J.G. Panther, W.W. Bennett, D.T. Welsh, P.R. Teasdale, Simultaneous Measurement of Trace Metal and Oxyanion Concentrations in Water using Diffusive Gradients in Thin Films with a ChelexMetsorb Mixed Binding Layer, Analytical Chemistry, 86 (2013) 427-434.

[24] K.W. Warnken, H. Zhang, W. Davison, Performance characteristics of suspended particulate reagent-iminodiacetate as a binding agent for diffusive gradients in thin films, Analytica Chimica Acta, 508 (2004) 41-51.

[25] S. Mason, R. Hamon, A. Nolan, H. Zhang, W. Davison, Performance of a Mixed Binding Layer for Measuring Anions and Cations in a Single Assay Using the Diffusive Gradients in Thin Films Technique, Analytical Chemistry, 77 (2005) 6339-6346.

[26] H.L. Price, P.R. Teasdale, D.F. Jolley, An evaluation of ferrihydrite- and Metsorb ${ }^{\mathrm{TM}}$-DGT techniques for measuring oxyanion species (As, Se, V, P): Effective capacity, competition and diffusion coefficients, Analytica Chimica Acta, 803 (2013) 56-65.

[27] J.P.A. Gustafsson, Windows Version of Visual MINTEQ 3.0; http://www2.Iwr.kth.se/english/OurSoftware/vminteq/.

[28] H. Österlund, S. Chlot, M. Faarinen, A. Widerlund, I. Rodushkin, J. Ingri, D.C. Baxter, Simultaneous measurements of $\mathrm{As}, \mathrm{Mo}, \mathrm{Sb}, \mathrm{V}$ and $\mathrm{W}$ using a ferrihydrite diffusive gradients in thin films (DGT) device, Analytica Chimica Acta, 682 (2010) 59-65. 
[29] J. Luo, H. Zhang, J. Santner, W. Davison, Performance Characteristics of Diffusive Gradients in Thin Films Equipped with a Binding Gel Layer Containing Precipitated Ferrihydrite for Measuring Arsenic(V), Selenium(VI), Vanadium(V), and Antimony(V), Analytical Chemistry, 82 (2010) 8903-8909. [30] Y.-H. Li, S. Gregory, Diffusion of ions in sea water and in deep-sea sediments, Geochimica et Cosmochimica Acta, 38 (1974) 703-714.

[31] J.G. Panther, K.P. Stillwell, K.J. Powell, A.J. Downard, Perfluorosulfonated lonomer-Modified Diffusive Gradients in Thin Films: Tool for Inorganic Arsenic Speciation Analysis, Analytical Chemistry, 80 (2008) 9806-9811.

[32] W. Li, H. Zhao, P.R. Teasdale, R. John, S. Zhang, Synthesis and characterisation of a polyacrylamide-polyacrylic acid copolymer hydrogel for environmental analysis of $\mathrm{Cu}$ and $\mathrm{Cd}$, Reactive and Functional Polymers, 52 (2002) 31-41.

[33] L.P. Yezek, H.P. van Leeuwen, Donnan Effects in the Steady-State Diffusion of Metal lons through Charged Thin Films, Langmuir, 21 (2005) 10342-10347.

[34] K.W. Warnken, H. Zhang, W. Davison, Trace Metal Measurements in Low lonic Strength Synthetic Solutions by Diffusive Gradients in Thin Films, Analytical Chemistry, 77 (2005) 5440-5446.

[35] T. Scheel, B. Jansen, A.J. Van Wijk, J.M. Verstraten, K. Kalbitz, Stabilization of dissolved organic matter by aluminium: a toxic effect or stabilization through precipitation?, European Journal of Soil Science, 59 (2008) 1122-1132.

[36] H. Zhang, DGT Research Ltd.; www.dgtresearch.com. 


\begin{tabular}{cccc}
\hline & $\begin{array}{c}\text { Mean MBL } \\
\text { blanks }\end{array}$ & $\begin{array}{c}\text { MDL for } \\
\text { open gel }\end{array}$ & $\begin{array}{c}\text { MDL for } \\
\text { restricted gel }\end{array}$ \\
$\mathbf{A l}$ & $97.9 \pm 11.9$ & 3.0 & 1.6 \\
$\mathbf{C d}$ & $0.11 \pm 0.15$ & 0.03 & 0.01 \\
$\mathbf{C o}$ & $0.61 \pm 0.07$ & 0.01 & 0.01 \\
$\mathbf{C u}$ & $23.6 \pm 6.7$ & 0.68 & 0.62 \\
$\mathbf{M n}$ & $2.68 \pm 0.88$ & 0.13 & 0.18 \\
$\mathbf{N i}$ & $6.81 \pm 0.46$ & 0.09 & 0.02 \\
$\mathbf{P b}$ & $6.35 \pm 3.10$ & 0.23 & 0.41 \\
$\mathbf{Z n}$ & $85.6 \pm 18.0$ & 2.2 & 3.4 \\
$\mathbf{A s}$ & $0.85 \pm 0.23$ & 0.01 & 0.04 \\
$\mathbf{M o}$ & $1.34 \pm 0.43$ & 0.05 & 0.07 \\
$\mathbf{S b}$ & $0.45 \pm 0.16$ & 0.02 & 0.04 \\
$\mathbf{V}$ & $1.39 \pm 0.48$ & 0.04 & 0.07 \\
$\mathbf{W}$ & $2.01 \pm 0.66$ & 0.06 & 0.16 \\
\hline
\end{tabular}

Table 1. Mean blanks (ng) and calculated method detection limits (MDL, $n g \mathrm{~mL}^{-1}$ ) for DGT-MBL using diffusion coefficients obtained from current study. Conditions: $\Delta \mathrm{g}=0.09 \mathrm{~cm} ; \mathrm{t}=32 \mathrm{~h} ; \mathrm{A}=3.14 \mathrm{~cm}^{2}$. 


\begin{tabular}{|c|c|c|c|c|c|c|c|c|c|c|c|}
\hline \multirow{3}{*}{ Element } & \multicolumn{6}{|c|}{ Diffusion coefficient $\left(\mathrm{D}_{\mathrm{DGT}}\right)^{\mathrm{a}}$} & \multicolumn{4}{|c|}{$\left(\mathbf{D}_{\mathrm{DGT}} / \mathbf{D}_{\mathrm{W}}\right)$} & \multirow{3}{*}{$\begin{array}{c}\text { Literature } \\
\text { ODL }\end{array}$} \\
\hline & \multicolumn{2}{|c|}{ ODL } & \multicolumn{2}{|c|}{ RDL } & \multicolumn{2}{|c|}{$(\text { RDL / ODL })^{\mathbf{b}}$} & \multicolumn{2}{|c|}{ ODL } & \multicolumn{2}{|c|}{ RDL } & \\
\hline & pH 7.04 & pH 4.01 & pH 7.04 & pH 4.01 & $\begin{array}{c}\text { pH } \\
7.04\end{array}$ & $\begin{array}{c}\mathrm{pH} \\
4.01\end{array}$ & $\begin{array}{c}\text { pH } \\
7.04\end{array}$ & $\begin{array}{c}\text { pH } \\
4.01\end{array}$ & $\begin{array}{c}\text { pH } \\
7.04\end{array}$ & $\begin{array}{c}\text { pH } \\
\mathbf{4 . 0 1}\end{array}$ & \\
\hline $\mathbf{A} \mathbf{l}^{\mathbf{c}}$ & $5.83 \pm 0.26$ & $4.28 \pm 0.19$ & $4.01 \pm 0.20$ & $3.10 \pm 0.11$ & $\begin{array}{c}0.69 \pm \\
0.07\end{array}$ & $\begin{array}{c}0.72 \pm \\
0.06\end{array}$ & 1.04 & 0.77 & 0.72 & 0.55 & $\begin{array}{c}5.38[9] \\
4.36[9] \\
5.10[17]\end{array}$ \\
\hline Cd & $6.30 \pm 0.28$ & $5.56 \pm 0.21$ & $4.69 \pm 0.21$ & $4.07 \pm 0.18$ & $\begin{array}{c}0.74 \pm \\
0.06\end{array}$ & $\begin{array}{c}0.73 \pm \\
0.06 \\
\end{array}$ & 0.88 & 0.78 & 0.65 & 0.57 & $\begin{array}{l}5.56[23] \\
5.36[17]\end{array}$ \\
\hline Co & $6.24 \pm 0.31$ & $5.88 \pm 0.20$ & $4.89 \pm 0.25$ & $4.48 \pm 0.17$ & $\begin{array}{c}0.78 \pm \\
0.07 \\
\end{array}$ & $\begin{array}{c}0.76 \pm \\
0.05 \\
\end{array}$ & 0.89 & 0.84 & 0.70 & 0.64 & $\begin{array}{l}5.29[23] \\
5.99[17]\end{array}$ \\
\hline $\mathrm{Cu}$ & $6.04 \pm 0.34$ & $5.34 \pm 0.19$ & $4.70 \pm 0.27$ & $4.19 \pm 0.13$ & $\begin{array}{c}0.78 \pm \\
0.08 \\
\end{array}$ & $\begin{array}{c}0.78 \pm \\
0.05 \\
\end{array}$ & 0.82 & 0.73 & 0.64 & 0.57 & $\begin{array}{l}5.61[23] \\
6.25[17]\end{array}$ \\
\hline Mn & $5.43 \pm 0.22$ & $5.11 \pm 0.22$ & $4.07 \pm 0.18$ & $4.01 \pm 0.16$ & $\begin{array}{c}0.75 \pm \\
0.06\end{array}$ & $\begin{array}{c}0.78 \pm \\
0.06\end{array}$ & 0.79 & 0.74 & 0.59 & 0.58 & $\begin{array}{l}4.68[23] \\
5.82[17]\end{array}$ \\
\hline $\mathrm{Ni}$ & $6.08 \pm 0.26$ & $5.65 \pm 0.22$ & $4.69 \pm 0.23$ & $4.05 \pm 0.20$ & $\begin{array}{c}0.77 \pm \\
0.07 \\
\end{array}$ & $\begin{array}{c}0.72 \pm \\
0.06\end{array}$ & 0.90 & 0.83 & 0.69 & 0.60 & $\begin{array}{l}5.13[23] \\
6.29[17]\end{array}$ \\
\hline $\mathbf{P b}$ & $8.13 \pm 0.68$ & $7.70 \pm 0.29$ & $5.89 \pm 0.48$ & $5.56 \pm 0.10$ & $\begin{array}{c}0.72 \pm \\
0.12\end{array}$ & $\begin{array}{c}0.72 \pm \\
0.04\end{array}$ & 0.86 & 0.81 & 0.62 & 0.59 & $\begin{array}{l}8.03[23] \\
9.91[17]\end{array}$ \\
\hline $\mathbf{Z n}$ & $6.23 \pm 0.54$ & $5.78 \pm 0.24$ & $4.71 \pm 0.33$ & $4.30 \pm 0.15$ & $\begin{array}{c}0.76 \pm \\
0.11\end{array}$ & $\begin{array}{c}0.74 \pm \\
0.05\end{array}$ & 0.87 & 0.81 & 0.66 & 0.60 & $\begin{array}{l}6.22[23] \\
4.38[17]\end{array}$ \\
\hline As & $5.59 \pm 0.21$ & $5.96 \pm 0.20$ & $3.88 \pm 0.19$ & $4.24 \pm 0.23$ & $\begin{array}{c}0.69 \pm \\
0.06\end{array}$ & $\begin{array}{c}0.71 \pm \\
0.06\end{array}$ & 0.62 & 0.66 & 0.43 & 0.47 & $\begin{array}{c}6.02[23] \\
6.05[26] \\
6.83[6] \\
6.78[8] \\
5.26[28] \\
5.25[29]\end{array}$ \\
\hline Mo & $6.67 \pm 0.37$ & $7.24 \pm 0.19$ & $4.40 \pm 0.19$ & $4.94 \pm 0.16$ & $\begin{array}{c}0.66 \pm \\
0.07\end{array}$ & $\begin{array}{c}0.68 \pm \\
0.04\end{array}$ & 0.67 & 0.73 & 0.44 & 0.50 & $\begin{array}{c}6.33[23] \\
6.81[8] \\
5.42[28]\end{array}$ \\
\hline Sb & $6.25 \pm 0.28$ & $6.74 \pm 0.24$ & $4.48 \pm 0.26$ & $4.93 \pm 0.22$ & $\begin{array}{c}0.72 \pm \\
0.07\end{array}$ & $\begin{array}{c}0.73 \pm \\
0.06\end{array}$ & 0.76 & 0.82 & 0.54 & 0.60 & $\begin{array}{c}6.22[23] \\
6.86[8] \\
5.38[28] \\
5.46[29]\end{array}$ \\
\hline $\mathbf{V}$ & $8.24 \pm 0.50$ & $8.92 \pm 0.27$ & $6.19 \pm 0.30$ & $6.84 \pm 0.34$ & $\begin{array}{c}0.75 \pm \\
0.08\end{array}$ & $\begin{array}{c}0.77 \pm \\
0.06\end{array}$ & - & - & - & - & $\begin{array}{c}7.98[23] \\
8.02[8] \\
6.73[26] \\
6.66[28] \\
6.26[29]\end{array}$ \\
\hline W & $6.05 \pm 0.31$ & $6.50 \pm 0.34$ & $4.21 \pm 0.23$ & $4.72 \pm 0.27$ & $\begin{array}{c}0.70 \pm \\
0.07\end{array}$ & $\begin{array}{c}0.73 \pm \\
0.08\end{array}$ & 0.66 & 0.70 & 0.46 & 0.51 & $\begin{array}{c}6.88[23] \\
6.26[8] \\
5.56[28]\end{array}$ \\
\hline
\end{tabular}

Table 2. Diffusion coefficients $\left(D_{\text {DGT }}\right)\left(\times 10^{-6} \mathrm{~cm}^{2} \mathrm{~s}^{-1}\right)$ of cations and oxyanions calculated from time-series deployments of DGT-MBL with open diffusive layer (ODL) and restricted diffusive layer (RDL) at pH 7.04 and 4.01, adjusted to $25^{\circ} \mathrm{C}$ [refer to section 2.3.1 for conditions of the experiment]. $\mathrm{D}_{\mathrm{W}}$ is the diffusion coefficient of

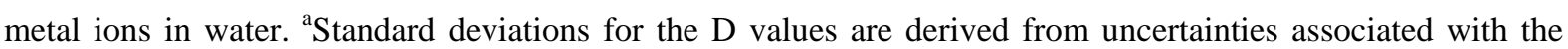
slopes and the analyte concentration using the square root of the sum of the individual errors squared. ${ }^{\mathrm{b}}$ Standard deviations for the ratios are derived from uncertainties associated with the diffusion coefficient values using the square root of the sum of the individual errors squared. ${ }^{\mathrm{c}} \mathrm{Al}$ was determined at $\mathrm{pH} 8.30$ instead of 7.04. 


\begin{tabular}{ccc}
\hline & \multicolumn{2}{c}{$\mathbf{D}_{\mathbf{D G T}}(\mathbf{p H} \mathbf{4 . 0 1}) / \mathbf{D}_{\mathbf{D G T}}(\mathbf{p H} \mathbf{7 . 0 4})^{\mathbf{a}}$} \\
& $\mathbf{O D L}$ & $\mathbf{R D L}$ \\
$\mathbf{A l}^{\mathbf{b}}$ & $0.73 \pm 0.06$ & $0.77 \pm 0.06$ \\
$\mathbf{C d}$ & $0.88 \pm 0.06$ & $0.87 \pm 0.06$ \\
$\mathbf{C o}$ & $0.94 \pm 0.06$ & $0.92 \pm 0.06$ \\
$\mathbf{C u}$ & $0.88 \pm 0.07$ & $0.89 \pm 0.06$ \\
$\mathbf{M n}$ & $0.94 \pm 0.06$ & $0.99 \pm 0.06$ \\
$\mathbf{N i}$ & $0.93 \pm 0.06$ & $0.87 \pm 0.07$ \\
$\mathbf{P b}$ & $0.95 \pm 0.09$ & $0.94 \pm 0.08$ \\
$\mathbf{Z n}$ & $0.93 \pm 0.10$ & $0.91 \pm 0.08$ \\
$\mathbf{A s}$ & $1.07 \pm 0.05$ & $1.09 \pm 0.07$ \\
$\mathbf{M o}$ & $1.09 \pm 0.06$ & $1.12 \pm 0.05$ \\
$\mathbf{S b}$ & $1.08 \pm 0.06$ & $1.10 \pm 0.07$ \\
$\mathbf{V}$ & $1.08 \pm 0.07$ & $1.11 \pm 0.07$ \\
$\mathbf{W}$ & $1.07 \pm 0.07$ & $1.12 \pm 0.08$ \\
& & \\
\hline
\end{tabular}

Table 3. The ratio of the calculated diffusion coefficients at $\mathrm{pH} 4.01$ to the diffusion coefficients at $\mathrm{pH} 7.04$

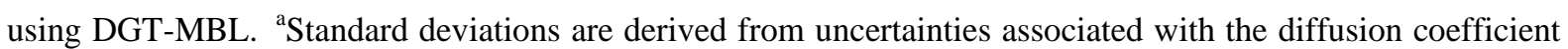
values using the square root of the sum of the individual errors squared. ${ }^{\mathrm{b}} \mathrm{Al}$ was determined at $\mathrm{pH} 8.30$ instead of 7.04 . 


\begin{tabular}{|c|c|c|c|c|c|c|c|}
\hline \multirow{2}{*}{ Element } & \multicolumn{3}{|c|}{ Diffusion coefficient $\left(\mathbf{D}_{\text {cell }}\right)^{\mathrm{a}}$} & \multicolumn{2}{|c|}{$\left(\mathrm{D}_{\text {cell }} / \mathrm{D}_{\mathrm{DGT}}\right)^{\mathrm{b}, \mathrm{c}}$} & \multicolumn{2}{|c|}{ Literature } \\
\hline & ODL & RDL & RDL / ODL & ODL & RDL & ODL & RDL \\
\hline Al & $4.14 \pm 0.13$ & $2.82 \pm 0.38$ & $0.68 \pm 0.14$ & $\begin{array}{c}0.97 \pm \\
0.05\end{array}$ & $\begin{array}{c}0.91 \pm \\
0.14\end{array}$ & $\begin{array}{l}4.75[36] \\
3.82[35]\end{array}$ & $2.90[35]$ \\
\hline $\mathbf{C d}$ & $5.36 \pm 0.18$ & $3.87 \pm 0.16$ & $0.72 \pm 0.05$ & $\begin{array}{c}0.96 \pm \\
0.05\end{array}$ & $\begin{array}{c}0.95 \pm \\
0.06\end{array}$ & $\begin{array}{l}5.52[23] \\
6.45[21] \\
6.09[36]\end{array}$ & $\begin{array}{l}3.58[22] \\
4.02[21]\end{array}$ \\
\hline Co & $5.03 \pm 0.17$ & $3.59 \pm 0.15$ & $0.71 \pm 0.05$ & $\begin{array}{c}0.86 \pm \\
0.05\end{array}$ & $\begin{array}{c}0.80 \pm \\
0.06\end{array}$ & $\begin{array}{l}5.17[23] \\
5.94[36]\end{array}$ & $3.64[22]$ \\
\hline $\mathbf{C u}$ & $5.27 \pm 0.19$ & $3.82 \pm 0.17$ & $0.72 \pm 0.06$ & $\begin{array}{c}0.99 \pm \\
0.05\end{array}$ & $\begin{array}{c}0.91 \pm \\
0.05\end{array}$ & $\begin{array}{l}5.75[23] \\
6.30[21] \\
6.23[36]\end{array}$ & $\begin{array}{l}3.72[22] \\
4.40[21]\end{array}$ \\
\hline Mn & $4.95 \pm 0.18$ & $3.52 \pm 0.15$ & $0.71 \pm 0.06$ & $\begin{array}{c}0.97 \pm \\
0.06\end{array}$ & $\begin{array}{c}0.88 \pm \\
0.06\end{array}$ & $\begin{array}{l}4.88[23] \\
5.85[36]\end{array}$ & $3.64[22]$ \\
\hline $\mathbf{N i}$ & $5.13 \pm 0.18$ & $3.68 \pm 0.15$ & $0.72 \pm 0.05$ & $\begin{array}{c}0.91 \pm \\
0.05\end{array}$ & $\begin{array}{c}0.91 \pm \\
0.06\end{array}$ & $\begin{array}{l}5.21[23] \\
5.77[36] \\
6.18[21]\end{array}$ & $\begin{array}{l}3.75[22] \\
4.28[21]\end{array}$ \\
\hline $\mathbf{P b}$ & $6.80 \pm 0.24$ & $4.99 \pm 0.21$ & $0.73 \pm 0.05$ & $\begin{array}{c}0.88 \pm \\
0.05\end{array}$ & $\begin{array}{c}0.90 \pm \\
0.05\end{array}$ & $\begin{array}{l}7.75[23] \\
8.03[36]\end{array}$ & $\begin{array}{l}5.28[22] \\
6.14[21]\end{array}$ \\
\hline Zn & $5.39 \pm 0.23$ & $3.84 \pm 0.18$ & $0.71 \pm 0.06$ & $\begin{array}{c}0.93 \pm \\
0.06\end{array}$ & $\begin{array}{c}0.89 \pm \\
0.06\end{array}$ & $\begin{array}{l}5.47[23] \\
6.08[36]\end{array}$ & $4.59[22]$ \\
\hline As & $5.36 \pm 0.22$ & $3.83 \pm 0.08$ & $0.71 \pm 0.05$ & $\begin{array}{c}0.90 \pm \\
0.05\end{array}$ & $\begin{array}{c}0.90 \pm \\
0.06\end{array}$ & $\begin{array}{c}5.26[23] \\
5.21[28] \\
5.54[8] \\
5.57[6] \\
6.10[26] \\
5.18[29]\end{array}$ & - \\
\hline Mo & $5.58 \pm 0.24$ & $3.96 \pm 0.09$ & $0.71 \pm 0.05$ & $\begin{array}{c}0.77 \pm \\
0.05\end{array}$ & $\begin{array}{c}0.80 \pm \\
0.04\end{array}$ & $\begin{array}{c}5.18[23] \\
5.96[28] \\
6.28[8]\end{array}$ & - \\
\hline $\mathbf{S b}$ & $5.50 \pm 0.22$ & $4.14 \pm 0.07$ & $0.75 \pm 0.04$ & $\begin{array}{c}0.82 \pm \\
0.05\end{array}$ & $\begin{array}{c}0.84 \pm \\
0.05\end{array}$ & $\begin{array}{c}4.90[23] \\
5.55[28] \\
5.40[29] \\
6.04[8]\end{array}$ & - \\
\hline $\mathbf{V}$ & $3.88 \pm 0.14$ & $2.67 \pm 0.06$ & $0.69 \pm 0.04$ & $\begin{array}{c}0.44 \pm \\
0.05\end{array}$ & $\begin{array}{c}0.39 \pm \\
0.06\end{array}$ & $\begin{array}{c}3.75[23] \\
6.72[28] \\
7.14[8] \\
6.70[26] \\
6.48[29]\end{array}$ & $3.45[22]$ \\
\hline $\mathbf{W}$ & $4.28 \pm 0.22$ & $2.98 \pm 0.06$ & $0.70 \pm 0.05$ & $\begin{array}{c}0.66 \pm \\
0.07\end{array}$ & $\begin{array}{c}0.63 \pm \\
0.06\end{array}$ & $\begin{array}{c}6.22[23] \\
6.89[8] \\
5.45[28]\end{array}$ & - \\
\hline
\end{tabular}

Table 4. Diffusion coefficients $\left(\times 10^{-6} \mathrm{~cm}^{2} \mathrm{~s}^{-1}\right)$ of cations and oxyanions in open diffusive layer (ODL) and restricted diffusive layer (RDL) determined using diffusion cells, adjusted to $25^{\circ} \mathrm{C}$. ${ }^{\mathrm{a}}$ Standard deviations for the D values are derived from uncertainties associated with the slopes and the analyte concentration using the square root of the sum of the individual errors squared. 'btandard deviations for the ratios are derived from uncertainties associated with the diffusion coefficient values. ${ }^{c}$ Conditions: $\mathrm{D}_{\text {cell }}$ values at $\mathrm{pH} 4.00$ and $\mathrm{D}_{\mathrm{DGT}}$ values at $\mathrm{pH} 4.01$. 

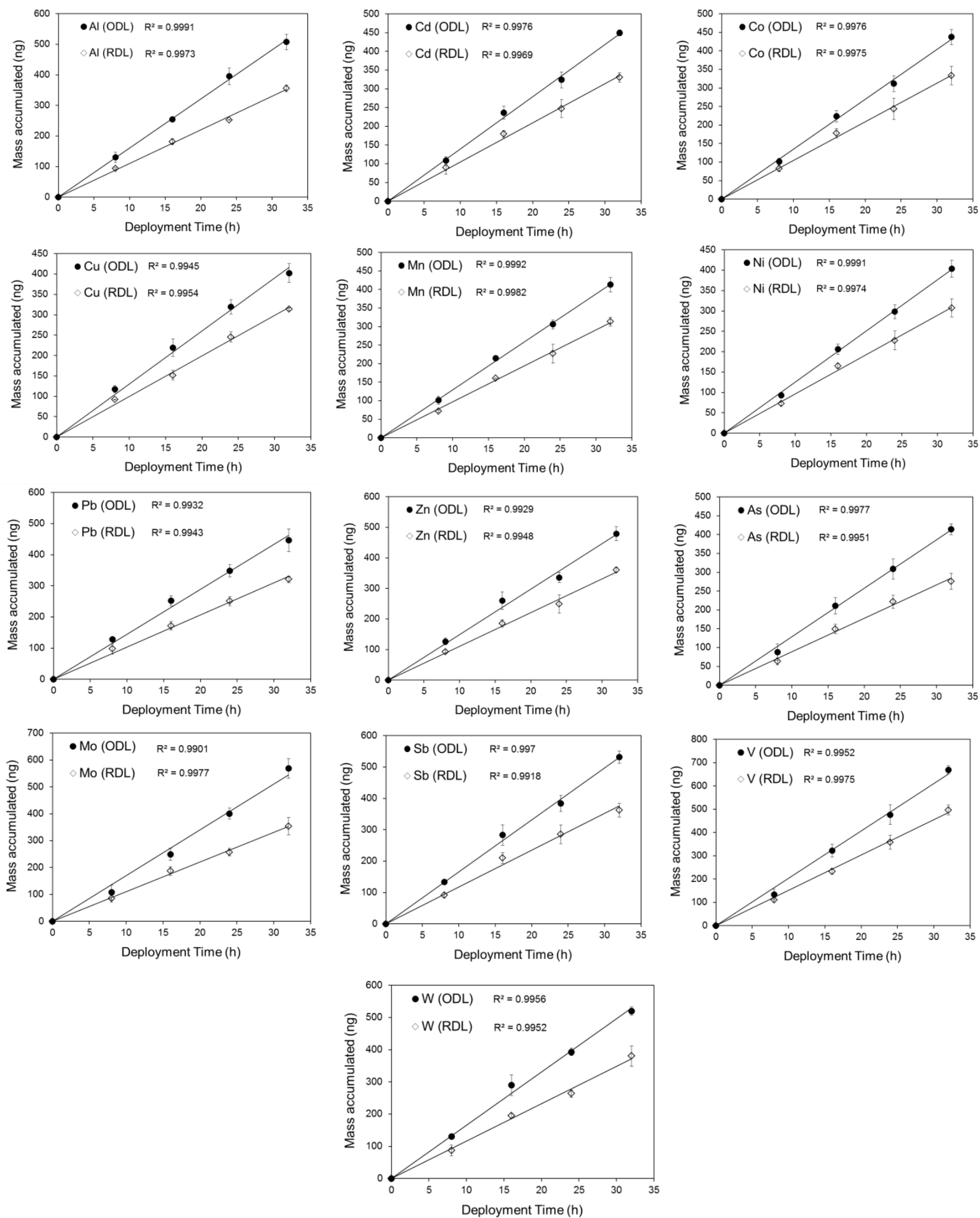

Figure 1. Time-series accumulation of cations and oxyanions by DGT samplers equipped with DGT-MBL using two different diffusive gels: open gel (ODL) and restricted gel (RDL). Conditions: $\mathrm{pH} 7.04$ and $0.01 \mathrm{~mol}$ $\mathrm{L}^{-1} \mathrm{NaNO}_{3} / 0.004 \mathrm{~mol} \mathrm{~L}^{-1} \mathrm{Mg}\left(\mathrm{NO}_{3}\right)_{2}\left[\mathrm{pH} 8.30\right.$ and $0.01 \mathrm{~mol} \mathrm{~L}^{-1} \mathrm{NaNO}_{3} / 0.0005 \mathrm{~mol} \mathrm{~L}^{-1} \mathrm{NaHCO}_{3}$ for $\left.\mathrm{Al}\right]$. Average analyte concentration (ng mL $\left.{ }^{-1}\right): 21.57 \mathrm{Al} ; 17.27 \mathrm{Cd} ; 16.57 \mathrm{Co} ; 16.64 \mathrm{Cu} ; 18.52 \mathrm{Mn} ; 16.09 \mathrm{Ni} ; 13.75$ $\mathrm{Pb}$; 18.39 Zn; 18.46 As; 20.19 Mo; 21.10 Sb; 18.97 V; $21.79 \mathrm{~W}$. 